\title{
Response of Two Sugar Beet Varieties to Chicken Manure and Phosphorine Application
}

\author{
Abou El Seoud I. I. A ${ }^{1}$.Elham, A. Badr ${ }^{2}$ and Elshimaa, A.E ${ }^{3}$
}

\begin{abstract}
The present study was conducted to investigate the effect of chicken manure at zero, 10 and 20 ton/fed.rates and biofertilization (phosphate dissolving bacteria PDB (Bacillus megaterium var. phosphaticum inoculation)) on growth, chemical composition, yield and sugar quality of two sugar beet varieties ('Lados' and ' $T$

WS $\left.1436^{\prime}\right)$. The experiment was carried out at South Tahrir Region - El-Behira during the two successive growing winter seasons of $2006 / 2007$ and $2007 / 2008$. The experimental design used was a split split plot with four replicates. All data showed that Lados gave the highly significant difference compared to TWS 1436 in all growth attributes and sugar beet quality parameters except for purity \%, $\mathrm{Na} \%$ and extractable sucrose \%. Also, the results showed that with increasing chicken manure rates from control to 10 and 20 ton/fed., the means of growth attributes and sugar beet quality parameters tended to increase significantly at the different sample dates in both seasons, except T.S.S.\% and A.C. which were reduced significantly in both seasons. All growth attributes values at the different sample dates in both seasons were increased significantly by inoculation with phosphate dissolving bacteria. On the other hand, there was no significant difference in extractable sucrose $\%$, A.C. and $\propto$ amino-N between both varieties with and without PDB inoculation. In contrast, $\mathrm{K}, \mathrm{Na}$ and T.S.S. percentages were decreased significantly with inoculation by PDB. In each plant varieties, the response of sugar beet plants without PDB to the increasing of chicken manure (OM) application was vigorous and highly significant. On the other hand, the sugar beet plants inoculated with the PDB had a slight difference and not significant at different $O M$ rates in both varieties. In general, the bacteria have a significant effect when an organic matter level was very low. It can be concluded that inoculation with phosphate dissolving bacteria singly or application of chicken manure singly or combination of them had significantly increased all sugar beet growth attributes and quality parameters under the same conditions of this experiment. Also, Lados variety produced higher sugar beet growth attributes and quality parameters compared to the other variety TWS 1436
\end{abstract}

Keywords: sugar beet varieties; chicken manure; phosphate dissolving bacteria

${ }^{1}$ Department of Soil and Agricultural Chemistry,

Facultyof Agriculture, Saba Basha, Alexandria University

Egypt. E-mail:islamonline73@yahoo.com (corresponding author)

${ }^{2}$ Department of Field Crops Research, National Research Center,

Cairo, Egypt.

${ }^{3}$ Department of sugar crops, Agricultural Research Center,

Elsabahia, Alexandria, Egypt.

Received November 7, 2009, Accepted November 24, 2009

\section{INTRODUCTION}

Sugar beet (Beta vulgaris L.) is the second main source of sugar production after sugar cane not only in the world but also in Egypt. Sugar beet has a wide adaptability to grow in saline, alkaline, and new reclaimed calcareous soils. Also, it makes the soil in good condition for the benefit of the following crops especially by enhancing the aeration of the soil.

Many authors studied the difference between sugar beet varieties. Abd el-Wahab et al., (2005) found in the first season that the studied cultivars almost did not differ significantly from each other in root characteristics (length, diameter and weight) and juice quality (TSS\%, sucrose $\%$ and purity \%). In the second season only, Top and Kawemira cultivars recorded the highest root and sugar yield/fed.. While, Farida cultivar in the first season and Kawemira in the second one gave the highest top yield/fed. On the other hand, Omar (2007) reported that sugar beet varieties had no significant effect on root and sugar yields in both seasons. In contrast, sugar beet varieties had a significant effect on TSS\% and $\propto-$ amino $-\mathrm{N}$ in both seasons.

Many investigators used the organic matter to fertilize sugar beet. Negm et al., (2003) found that the application of organic manure, slightly increased cation exchange capacity, and reduced soil $\mathrm{pH}$. They found also that the available $\mathrm{N}, \mathrm{P}$ and $\mathrm{K}$ in the soil increased after the application of organic manure and reduced gradually by time to harvest. Also, Marinhovic et al., (2004) found that the application of organic fertilizer increased the yield from 1.41 to 2.13 ton/ha.. Similarly, Hassan (2005) indicated that the application of the organic fertilizers induced increases in the root yield, sugar yield, sucrose content, purity $\%$ and the concentrations of NPK and micronutrients ( $\mathrm{Fe}, \mathrm{Mn}$ and $\mathrm{Zn}$ ) in roots.

The use of biofertilizers in agricultural production, particularly in developing countries, still limited to minimize the high doses of chemical fertilizers in which enormous amounts of heavy metals and other 
environmental pollutants as well as to lower the agricultural production costs. The biofertilizers (microbial inoculants) are microbial preparations of rhizosphere microorganisms that posses definite roles, i.e. contribute the transformation of one or more of the plant nutrient elements and stimulate, to a great extent, plant growth by producing growth regulators (Gomaa, 1995).

Marrge and Bard (2001) studied the effect of phosphorine on sugar beet yield. They cleared that application of phosphorine significantly increased root and top and sugar yields/fed. Also, Badr (2004) mentioned that seed inoculation of sugar beet with biofertilizer significantly increased top and root yields as well as sugar yields. On the other hand, Nemeat-Alla (2004) found that seed inoculation of sugar beet with Cerealine or with Phosphorine or with both biofertilizers significantly affected root yield, but had no significant effect on root yield/plant, TSS\% and impurities in root juice in the two seasons.

The present study was designed to study the effect of chicken manure as organic fertilizer and inoculation with phosphorine (phosphate dissolving bacteria) on growth, yield, chemical composition and quality of two sugar beet varieties.

\section{MATERIALS AND METHODS}

Two field experiments were carried out in South Tahrir Region-El-Behira governorate during two successive growing winter seasons of 2006/2007 and 2007/2008. Before planting, soil samples $\left(\begin{array}{l}0-30 \mathrm{~cm}\end{array}\right)$ were randomly taken from the experimental site and analyzed for some physical and chemical properties according to the methods reported by Black (1965). The obtained values are given in Table 1 .
The experimental design was a split split plot with four replicates. Two sugar beet cultivars ('Lados' and 'TWS 1436') were used in the main plots. Three rates of chicken manure as zero, 10 and 20 ton/fed. were assigned in the sub-plot and the inoculation of phosphate dissolving bacteria (Bacillus megaterium var. phosphaticum) was arranged in the sub-sub plots.

Chicken manure produced by General Organization of Agriculture Equalization Fund (GOAEF) over sight Ministry of Agriculture, Egypt was used in this study. Its main chemical characteristics are presented in Table 2.

Phosphate dissolving bacteria (PDB) included Bacillus megaterium var. Phosphaticum obtained from Hanover University, Germany was added at the rate of 50 $\mathrm{ml} /$ plant (200g powder/100 L water) after transplanting.

Super phosphate fertilizer $\left(15.5 \% \mathrm{P}_{2} \mathrm{O}_{5}\right)$ at the rate of $100 \mathrm{~kg} \mathrm{P}_{2} \mathrm{O}_{5} / \mathrm{fed}$. and potassium sulphate $\left(48 \% \mathrm{~K}_{2} \mathrm{O}\right)$ at the rate of $50 \mathrm{~kg} \mathrm{~K}_{2} \mathrm{O} / \mathrm{fed}$. were applied during tillage operation. Nitrogen fertilizer in the form of ammonium nitrate $(33.5 \% \mathrm{~N})$ was added in side dressing at the rate of $90 \mathrm{~kg} / \mathrm{fed}$. in two equal parts, one half after thinning (before the first irrigation) and the other half before the second irrigation.

The seeds of sugar beet varieties were obtained from Sugar Crops Research Institute, Agricultural research center, Giza. Seeds ball were hand sown as the usual dry sowing on one side of the ridge in hills $25 \mathrm{~cm}$ a part at the rate of $4-5$ seed ball per hill on 2 and 13 October of 2006/2007 and 2007/2008 seasons respectively. The experimental basic unit area was $10.5 \mathrm{~m}^{2}$ and included 6 ridges, each of which $50 \mathrm{~cm}$ width and 3 meter length. Sugar beet plants were thinned two times to let one plant/hill. Plant samples were taken at 125, 150 and 170 days from sowing in both seasons to study the growth attributes.

Table 1. The main physical and chemical properties of the soil (of the two seasons)

\begin{tabular}{|c|c|c|c|c|c|c|c|c|c|c|c|c|c|c|}
\hline Year & Sand \% & $\begin{array}{c}\text { Silt } \\
\%\end{array}$ & $\begin{array}{c}\text { Clay } \\
\%\end{array}$ & $\begin{array}{c}\text { Soil } \\
\text { texture }\end{array}$ & pH & $\begin{array}{c}\text { EC } \\
\mathrm{dSm}^{-1} \\
(\mathbf{1 : 1})\end{array}$ & $\begin{array}{c}\text { OM } \\
\%\end{array}$ & $\begin{array}{c}\mathrm{CaCO}_{3} \\
\%\end{array}$ & $\begin{array}{l}\text { Total } \\
\text { N \% }\end{array}$ & $\begin{array}{l}\text { Av. P } \\
\mathrm{mg} / \mathrm{kg}\end{array}$ & $\begin{array}{l}\text { Av. Fe } \\
\mathrm{mg} / \mathrm{kg}\end{array}$ & $\begin{array}{c}\text { Av. Zn } \\
\mathrm{mg} / \mathrm{kg}\end{array}$ & $\begin{array}{c}\text { Av. Mn } \\
\mathrm{mg} / \mathrm{kg}\end{array}$ & Av. Cu mg/kg \\
\hline $2006 / 2007$ & 93.6 & 5.2 & 1.2 & Sandy & 7.8 & 2.62 & 0.32 & 4.6 & 0.03 & 5.5 & 3.6 & 1.1 & 0.3 & 2.7 \\
\hline $2007 / 2008$ & 92.1 & 5.8 & 2.1 & Sandy & 7.6 & 2.15 & 0.28 & 4.3 & 0.04 & 6.1 & 3.1 & 1.7 & 0.2 & 2.4 \\
\hline
\end{tabular}

Table 2. Chemical composition of the used chicken manure

OM \% $\quad$ OC \% $\quad$ C/N ratio $\quad$ pH $\quad \begin{gathered}\text { EC dS/m } \\ (1: 2)\end{gathered} \quad$ Total N \% $\quad$ Av. P mg/kg Av. K mg/kg



51.50
29.35
13.65
6.45
2.06
2.15
124
115

Samples of sugar beet plants were analyzed by wet digestion with $\mathrm{H}_{2} \mathrm{SO}_{4}-\mathrm{H}_{2} \mathrm{O}_{2}$ (Lowther 1980) to determine $\mathrm{Na}$ and $\mathrm{K}$ by flame photometer and $\mathrm{P}$ using vanadomolybdophosphoric method (Jackson, 1967). The growth analysis was calculated as following:

1- Crop Growth Rate (CGR) in g/day= (w2-w1)/(t2-t1). According to Radfords, (1967) where w1 and w2 refer to the day weight of plant at time t1 (150 days) and $\mathrm{t} 2$ (170 days) respectively.2- Relative Growth Rate $(\mathrm{RGR})$ in $\mathrm{g} / \mathrm{g} / \mathrm{week}=(\ln \mathrm{w} 2-\ln \mathrm{w} 1) /(\mathrm{t} 2-\mathrm{t} 1)$ according to Watson, (1958).

3- Net Assimilation Rate (NAR) in $\mathrm{g} / \mathrm{m}^{2} /$ day $=[(\mathrm{w} 2-$ w1)(ln A2 - ln A1)]/ [(t2 - t1)(A2- A1)] according to Radfords, (1967) where A1 and A2 refers to leaf area $\left(\mathrm{m}^{2}\right)$ at time $\mathrm{t} 1$ (150 days) and $\mathrm{t} 2$ (170 days) respectively. Also, the following quality parameters were estimated.

1 - Sucrose percentage $(\%)$

2- Potassium $\left(\mathrm{k}^{+}\right)$concentration $(\mathrm{mmol} / 100 \mathrm{gm}$ root fresh weight).

3- Sodium $\left(\mathrm{Na}^{+}\right)$concentration ( $\mathrm{mmol} / 100 \mathrm{gm}$ root fresh weight).

4- $\alpha$-amino-N (mmol/100gmroot fresh weight).

5- White extractable sugar $(\mathrm{B} \%)=$ sucrose $(\%)-\mathrm{D} \%$.

6- Purity $\%=\mathrm{B} \% /$ sucrose $\%$.

7- Total soluble solids (T.S.S $)=$ sucrose $\% /$ purity $\%$.

8- Alkaline coefficient (A.C) $=\left(\mathrm{k}^{+}+\mathrm{Na}^{+}\right) / \quad(\alpha$-amino$\mathrm{N})$ was calculated according to Harvey and Dutton (1993).

All quality parameters were estimated in Delta sugar Company limited laboratories at EL-Hamoul , Kafr ELSheikh.

The collected data (average of the two seasons) were subjected to ANOVA for a split split plot design according to Gomez and Gomez (1984).

\section{RESULTS AND DISCUSSION \\ I) Growth Attributes:}

The data in table (3) showed that Lados variety produced higher significant values compared to TWS 1436 variety especially at the second and third sample dates in root fresh weight, top fresh weight, top dry weight and leaf area index. On the other hand, Lados gave significantly higher values than the values of TWS 1436 for root diameter and root length at the first and second sample dates. In contrast, Omar (2007) reported that varieties did not exhibit any significant differences among them. On the other hand, there was no significant difference in CGR, RGR and NAR between the two sugar beet varieties during the two seasons.

The results showed that with increasing chicken manure rates application, the means of growth attributes tended to increase significantly at the different sample dates in both seasons. The increase in growth attributes with increasing chicken manure may be due to improving soil physical and chemical properties. Means of CGR were increased significantly with increasing chicken manure rates up to 20 ton/fed.. In contrast, there was no significant difference in RGR and NAR values with increasing chicken manure rates.

All growth attributes values (table 3) at the different sample dates in both seasons were increased significantly by inoculation with phosphate dissolving bacteria. On the other hand, there was no significant difference in RGR and NAR values by inoculation with bacteria. The beneficial effect of inoculation with phosphate dissolving bacteria was mainly due to increasing the release of $\mathrm{P}$ in the soil which is reflected in increasing $\mathrm{P}$ activity and the growth promoting substances produced by the bacteria. This may lead to the activation of cell division and cell enlargement and finally increasing the growth parameters (Patil, 1985). The observed results are in consistent in this respect with those obtained by Gonzalez et al., (1995) .

The interaction between the three factors under study (sugar beet varieties, chicken manure and phosphate dissolving bacteria) failed to exert any significant effect on most of growth attributes at all sample dates in both seasons. Only, the interaction effect between chicken manure and sugar beet varieties (OM x Var.) were significant on top fresh weight at 125 days, top dry weight at 150 days and root length at 150 days and highly significant on root dry weight at 150 days and on leaf area index at 125 and 150 days. On the other hand, the interaction effect between biofertilization and sugar beet varieties (Bio x Var.) was significant on leaf area index at 125 and 150 days and highly significant on root length at 125 days. Also, the interaction effect between chicken manure and biofertilizer (OM x Bio) was significant on root fresh weight at 170 days, top fresh weight at 170 days, root dry weight at 150 and 170 days, root diameter at 170 days and leaf area index at 170 days and highly significant on top fresh weight at 150 days, top dry weight at 170 days and root length at 150 days.

\section{II) Yield and chemical composition:}




\section{1- Shoot Yield and $P$ concentration:}

At harvest, the shoot yield (ton/fed) as affected by the different treatments presented in (Fig. 1). In each variety, the response of sugar beet plants without PDB to the increasing of chicken manure $(\mathrm{OM})$ application was vigorous and highly significant. These results are in agreement with those of Hepper and Warner (1983) and 


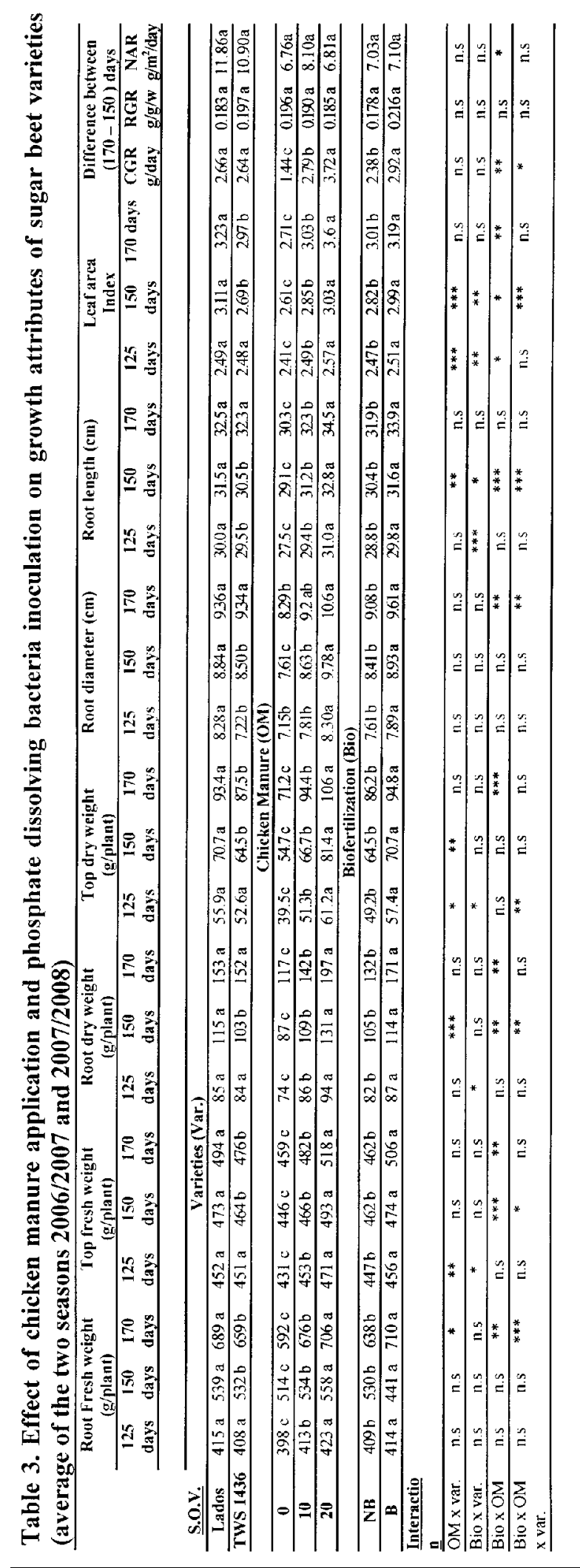


Soedarjo and Habte (1993). In the same line, Buraczynska (2004) concluded that the use of organic fertilizers led to a significant increase in shoot and root yields. The beneficial effects of organic matter might be explained by the presence of growth - promoting substance. In fact, various growth promoting compounds such as vitamins, amino acids, auxins and gibberellins are formed as organic matter decays. In contrast, Omar (2007) found that, top yield was not significantly affected by farmyard manure. On the other hand, the sugar beet plants inoculated with the PDB slightly affected at the different $\mathrm{OM}$ rates in both varieties. At low rate of $\mathrm{OM}$ at each plant variety, top yield of plant inoculated with PDB was significantly increased than the other plant without PDB. The top yield of sugar beet inoculated with PDB increased by $36 \%$ and $47 \%$ than the other plant without PDB in Lados and TWS 1436 respectively at low rate of OM. Phosphate dissolving from different $\mathrm{P}$ forms through producing chelating beet was increased by the addition of biofertilizers. In contrast, at high $\mathrm{OM}$ rate, there was no significant difference between $\mathrm{P}$ concentrations in the plants of the two varieties. That could be attributed to release amount of nutrients especially $\mathrm{P}$ from the OM decays which attained to the role of PDB becomes negligible or limited.

The shoot $\mathrm{P}$ concentration of plants with and without PDB increased significantly with increasing OM rates in both varieties. The $\mathrm{P}$ concentration in shoot of plants without PDB at higher OM rates was about 2.0 and 2.3fold higher than that at the lower OM rates of Lados and TWS 1436 varieties respectively. However, when the sugar beet inoculated with PDB, the $\mathrm{P}$ concentration in shoots of Lados and TWS 1436 varieties at higher OM rates was about 1.4 and 1.5-fold respectively higher than those at the lower OM rates (Fig. 2)

The shoot $\mathrm{P}$ concentration at which Lados and TWS 1436 varieties inoculated with PDB achieved more than $80 \%$ of its maximum yield amounted to 1.482 and 1.252 $\mathrm{mg}$ P/g d.m. In contrast, Lados and TWS 1436 varieties without PDB attained its highest yield at the relatively higher shoot $\mathrm{P}$ concentration of 1.821 and $1.624 \mathrm{mg} \mathrm{P} / \mathrm{g}$ d.m. respectively. The shoot $\mathrm{P}$ concentrations of Lados and TWS 1436 varieties inoculated with PDB attained its maximum yield were low being only about 0.8 (in both varieties) of that observed for plant without

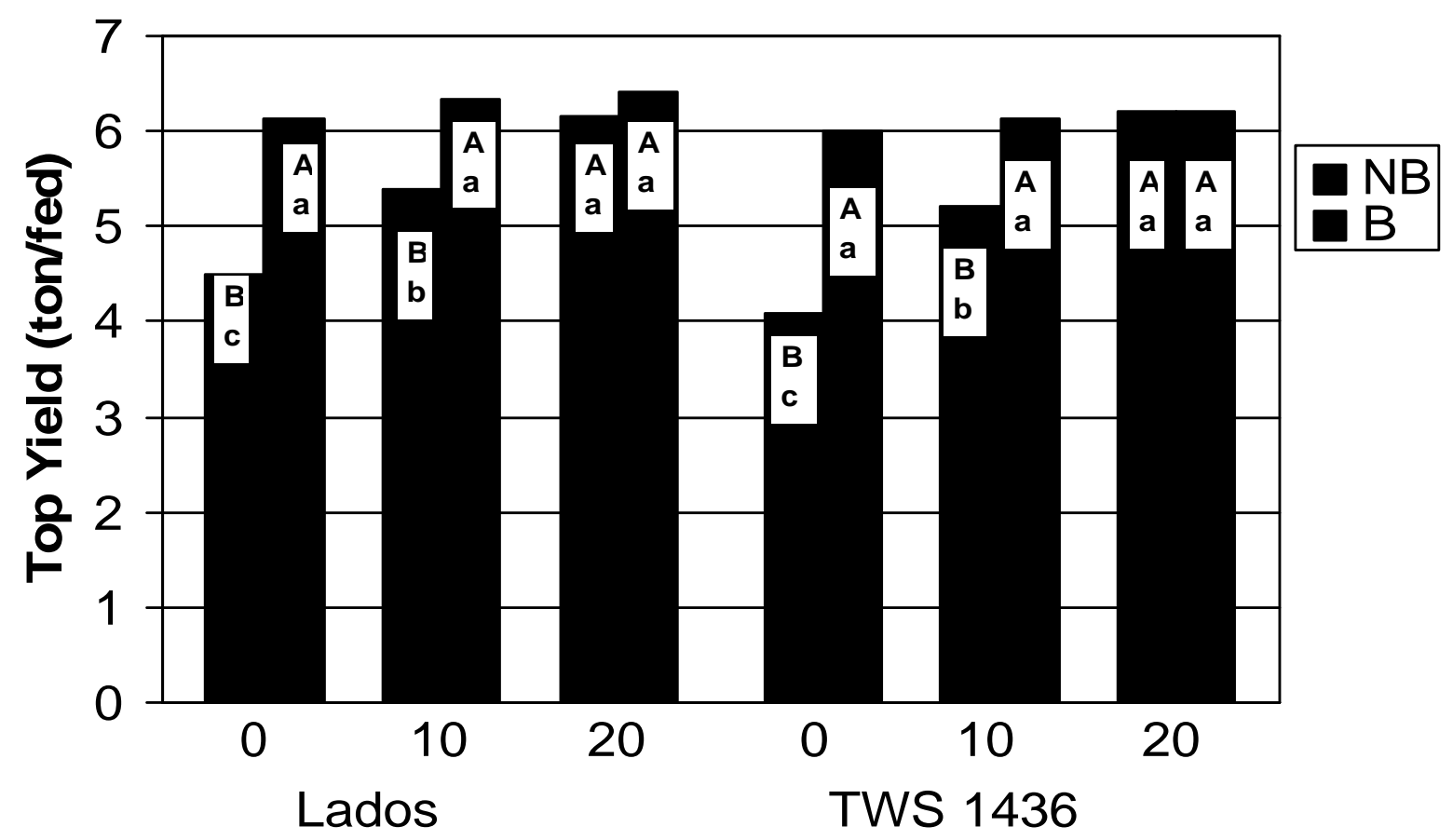

Figure 1. Top yield (ton/fed) of sugar beet varieties (Lados and TWS 1436) (average of two seasons 2006/2007 and 2007/2008 respectively) as affected by inoculation with (PDB) and chicken manure $(\mathrm{OM})$ application. ( $\mathrm{NB}=$ plants without $\mathrm{PDB} ; \mathrm{B}=$ plants with $\mathrm{PDB}$; different letters indicate significant difference; capital letters between inoculations; small letters between $\mathrm{OM}$ rates, $\mathrm{P} \leq \mathbf{0 . 0 5}$ ) 


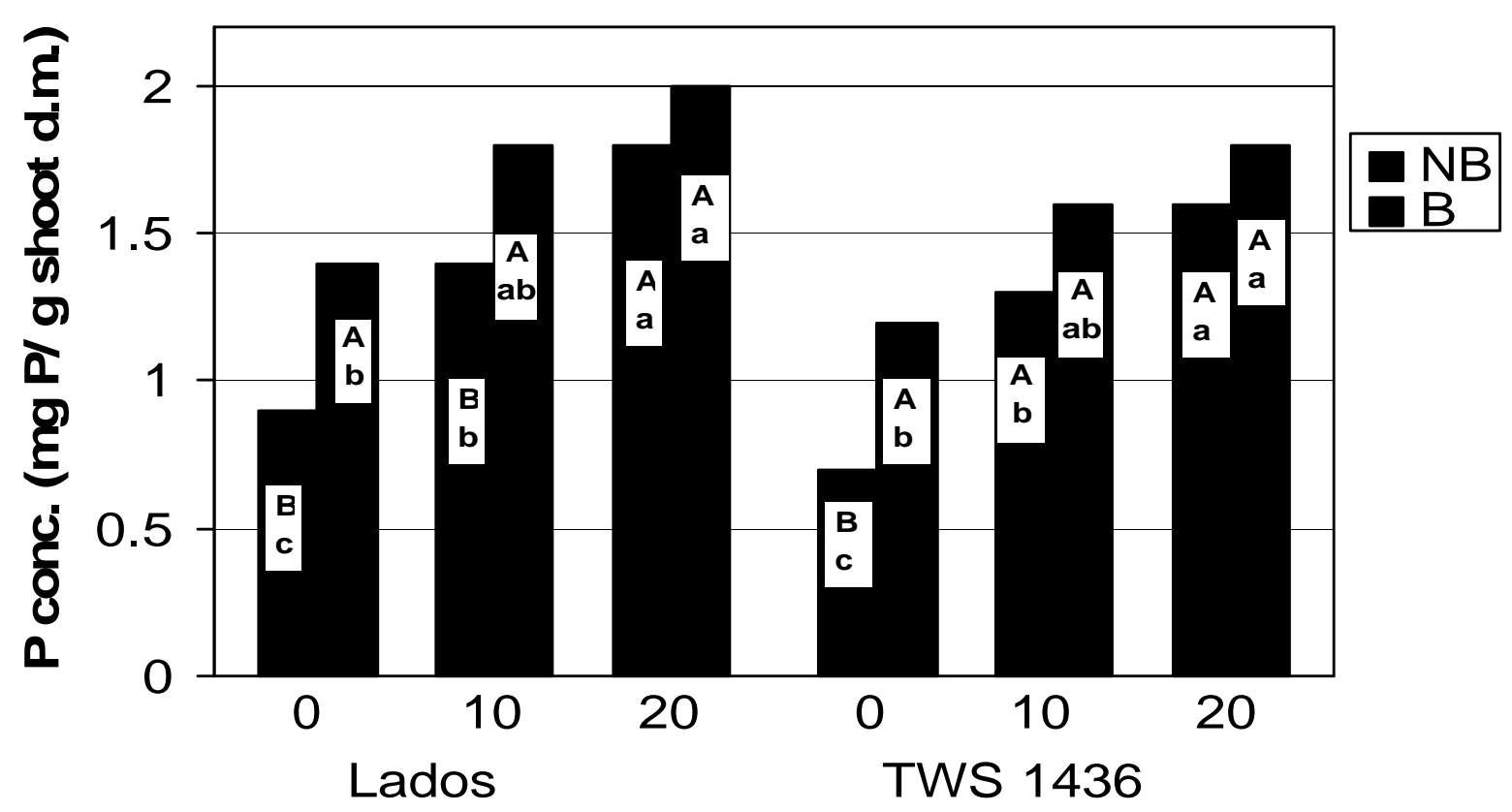

Figure 2. Shoot $P$ concentration (mg P/g d.m.) of sugar beet varieties (Lados and TWS 1436) (average of two seasons 2006/2007 and 2007/2008 respectively) as affected by inoculation with (PDB) and chicken manure (OM) application. $($ d.m. $=$ dry matter; $\mathrm{NB}=$ plants without PDB; $B$ = plants with PDB; different letters indicate significant difference; capital letters between inoculations; small letters between $O M$ rates, $P \leq 0.05$

inoculation. Therefore, based on the $\mathrm{P}$ use efficiency definition, plant inoculated with PDB had higher P use efficiencythan the plants without PDB.

On the other hand, at all OM rates, the $\mathrm{P}$ concentrations of Lados with and without PDB variety were higher than those of the other variety TWS 1436 under the same treatments (figure 2).

\section{2- Root Yield:}

At harvest, the total root yield (ton/fed) under all treatments were compared (fig. 3). At zero level of organic matter, there was a significant difference between the root yield of sugar beet plants with and without PDB for the two sugar beet varieties. The root yield of Lados and TWS 1436 inoculated with PDB were higher by about $19.8 \%$ and $20.2 \%$ than Lados and TWS 1436 without inoculation respectively. In the same line, Marrage and Bard (2001) and Nemeat - Alla (2004) found that inoculation of sugar beet with phosphorine significantly affected root yield/fed. In contrast, at the second and third levels of organic matter (10 and 20 ton/fed), there was no significant difference between root yield plants without PDB and that of the other plants inoculated with PDB of the two sugar beet varieties. In general, the PDB have a significant effect on root yield when the organic matter level was very low. On the other hand, root yield of sugar beet without PDB was increased significantly with increasing organic matter levels in Lados and TWS 1436 varieties. The obtained results are in agreement with those of Marinkovic et al., (2004), Hassan (2005), Elham (2006) and Omar (2007) who indicated that the application of the organic fertilizers induced increases in the root yield.

The response of TWS 1436 root yield to increasing the organic matter levels was higher than of the plants of the other variety (Lados). On the other words, the increases of Lados variety without PDB as a response to organic matter levels were 19.4 and $22.6 \%$ when the plants were subjected to 10 and 20 ton/fed respectively. The corresponding increases of TWS 1436 variety without PDB than the control were 16.9 and $23.1 \%$ respectively. The obtained results are in agreement with Marinkovic et al., (2004), Hassan (2005), Elham (2006) and Omar (2007). In contrast, the root yield of sugar beet plants inoculated with PDB was not affected significantly with increasing organic matter levels in both sugar beet varieties. On the other words, increasing organic matter from control to 10 and 20 ton/fed caused an increase in root yield of sugar beet inoculated with PDB by 2.2 and $4.9 \%$ only in the Lados variety and 1.9 and $4.1 \%$ only in the TWS 1436 variety. 
The root yield of Lados variety was higher than the TWS 1436 root yield at the different treatments.

\section{3- Sugar Yield:}

The sugar yield (ton/fed) of plants inoculated with PDB increased significantly compared to that of the other plant without bacteria at the first two levels of organic matter in both varieties (Lados and TWS 1436). On the other hands, the inoculation with PDB caused an increase in sugar yield by about $34 \%$ and $35.6 \%$ Lados and TWS 1436 varieties respectively at the first level of organic matter, and by about $19.7 \%$ and $19.1 \%$ in both varieties respectively at the second level of organic

matter (figure 4). In the same line, Marrge and Badr (2001); Khalil (2001); Nour El Din et al., (2002); Badr (2004); and Nemeat-Alla (2004) reported that the sugar yield of plants inoculated with PDB increased significantly compared to the other treatment without PDB. In contrast, there was no significant difference between sugar yield of plant with and without PDB in both varieties. The sugar yield of plants with bacteria increased only by $4.7 \%$ and $4.3 \%$ in Lados and TWS 1436 varieties respectively compared to the other plants without PDB at the highest level of organic matter (fig. 4). The reason that the PDB induced increasing in sugar yield especially at low level of organic matter could be due to modification of the structure of soil microbial communities, production of exudates by bacteria and changes in levels of available nutrients. On the other hand, at high level of organic matter, the role of PDB was limited and this could be due to the role of organic matter in increasing soil microbes and release the available nutrients (the same role of the bacteria which lead to decrease the effect of PDB at high level of organic matter). The data cleared that in both varieties (Lados and TWS 1436), the sugar yield of sugar beet plant without PDB was increased significantly with increasing organic matter levels (figure 4).

These results are similar with those obtained by Stumpe et al., (2000), Khalil (2001), Hassan (2005), and Omar (2007). Increasing organic matter from control (zero ton/fed) to 10 and 20 ton/fed caused an increase in sugar yield by about $13.5 \%$ and $34.9 \%$ in the first variety (Lados) and $14.4 \%$ and $33 \%$ in the second variety (TWS 1436). It could be concluded that increasing sugar yield as a response to the increase in organic matter may be attributed to the positive effect of organic matter on both root yield and purity $\%$. On the other hand, there was no significant difference between sugar yield of plant inoculated with PDB in both varieties at the different levels of organic matter (fig. 4).

Concerning the varieties, there was small difference among them and the Lados was higher than TWS 1436 at all treatments in sugar yield of plants (fig. 4).

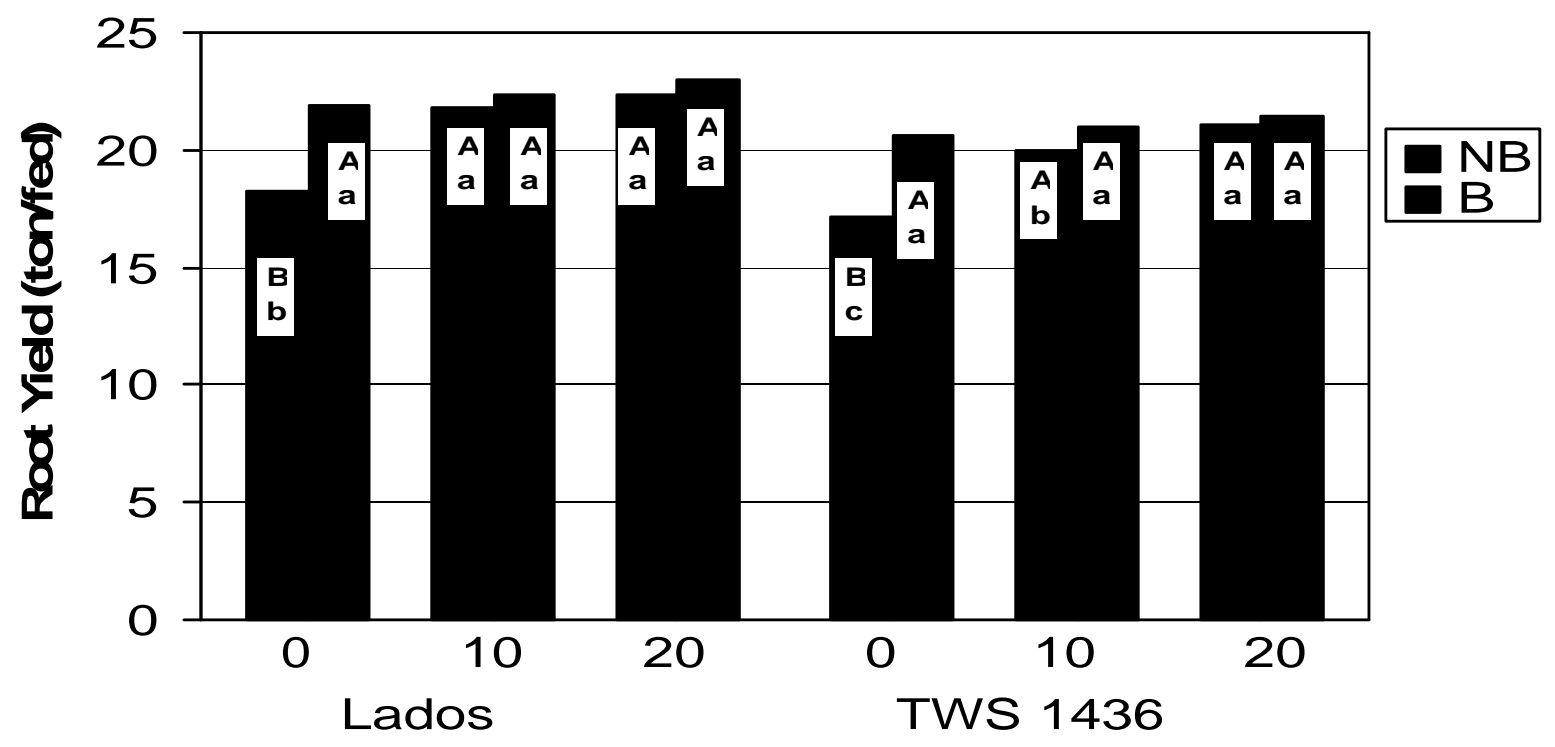

Figure 3. Root yield (ton/fed) of sugar beet varieties (Lados and TWS 1436) (average of two seasons 2006/2007 and 2007/2008 respectively) as affected by inoculation with (PDB) and chicken manure (OM) application. $(\mathrm{NB}=$ plants without $\mathrm{PDB} ; \mathrm{B}=$ plants with $\mathrm{PDB}$; different letters indicate significant difference; capital letters between inoculations; small letters between $\mathrm{OM}$ rates, $\mathrm{P} \leq \mathbf{0 . 0 5}$ ) 


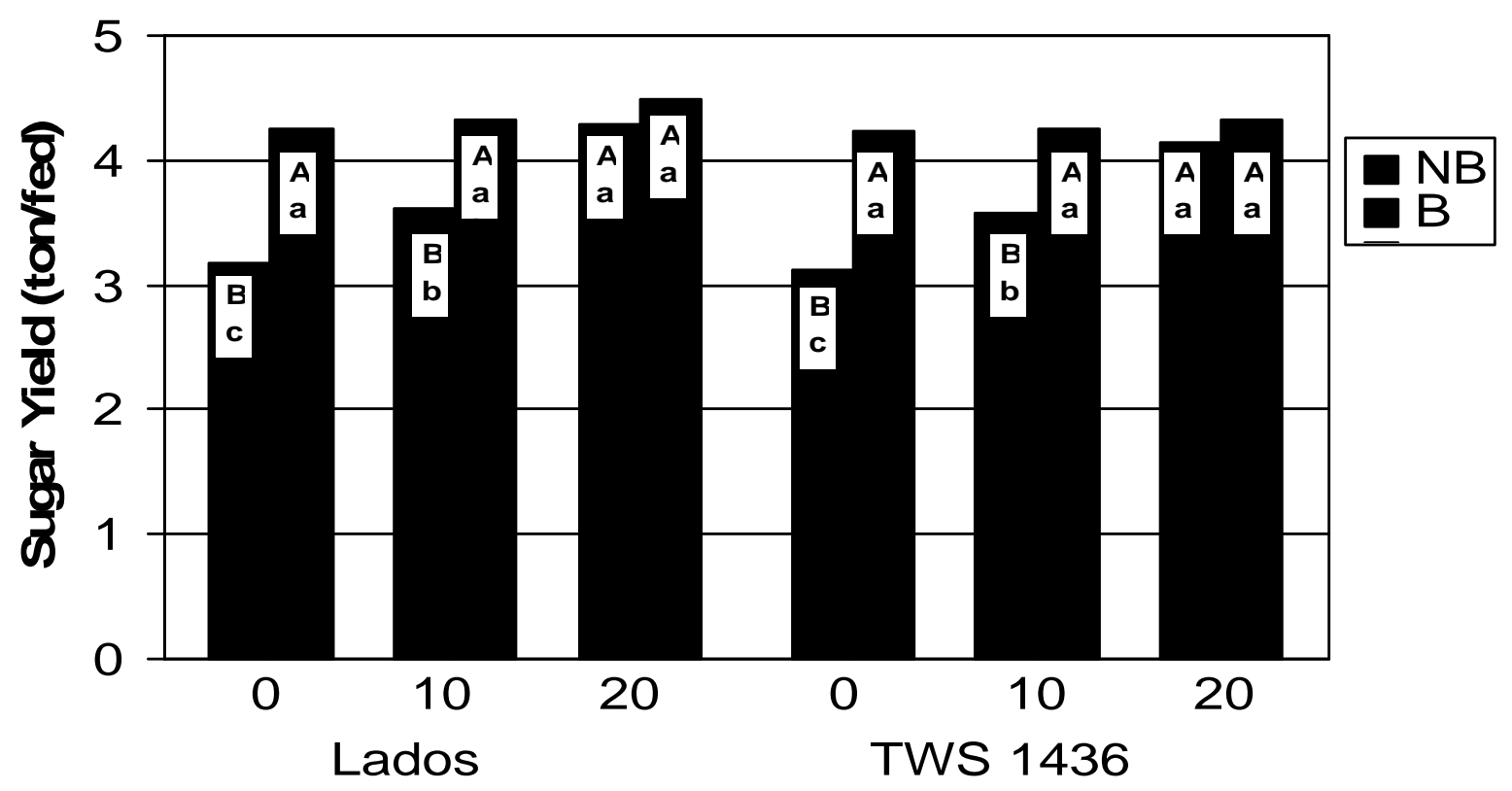

Figure 4. Sugar yield (ton/fed) of sugar beet varieties (Lados and TWS 1436) (average of two seasons 2006/2007 and 2007/2008 respectively) as affected by inoculation with (PDB) and chicken manure $(\mathrm{OM})$ application. $(\mathrm{NB}=$ plants without $\mathrm{PDB} ; \mathrm{B}=$ plants with $\mathrm{PDB}$; different letters indicate significant difference; capital letters between inoculations; small letters between $\mathrm{OM}$ rates, $\mathrm{P} \leq \mathbf{0 . 0 5}$ )

\section{4- Harvest index:}

The harvest index of Lados variety was significantly higher than the other sugar beet variety TWS 1436 (Table4). In contrast, Omar (2007) reported that TWS1436 gave the highest harvest index over the two seasons of the study, while Lados gave the lowest one. The harvest index increased significantly by increasing organic matter levels and this increase was mainly attributed to the increase in root yield by increasing the amount of organic matter. This result was in the same line with Omar (2007).

There was no significant difference between plants with and without PDB in harvest index of sugar beet (Table 4). A slight increase in harvest index of plants inoculated by PDB compared to the other plants without bacteria was observed.

\section{III) Quality parameters:}

\section{Effect of varieties:}

The data in table (4) cleared that; sucrose \% of Lados variety increased significantly compared to the other variety TWS 1436 . In contrast, Omar (2007) found that no considerable differences were observed in sucrose \% among varieties. On the other hand, no significant difference in purity $\%, \mathrm{Na} \%$ and extractable sucrose $\%$ were observed between the sugar beet varieties. Also, a slight positive effect of Lados on purity\% and extractable sucrose \% compared to the other variety TWS 1436 was noticed. Similarly, Omar (2007) reported that no significant differences were observed among varieties in the first season, however in the second season, the differences reached the significance level. In contrast, $\mathrm{K} \%$ and $\propto$-amino-N, of Lados variety decreased significantly compared to the values of TWS 1436. In the same line, Omar (2007) showed that, varieties had a negative significant effect on the soluble non sugar. The soluble non sugar $(\mathrm{K}, \mathrm{Na}$, and $\propto$-amino-N) in the roots are regarded as impurities because they interfere with sugar extraction. Also, the data in table (4) showed that, T.S.S.\% and A.C. of Lados decreased significantly compared to those of TWS 1436 variety. In contrast, Omar (2007) reported that no considerable differences in T.S.S. $\%$ and A.C. were found among varieties across the two seasons of the study.

\section{Effect of organic matter:}

Table (4) showed that, sucrose \%, purity $\%$ and extractable sucrose $\%$ were increased significantly with 



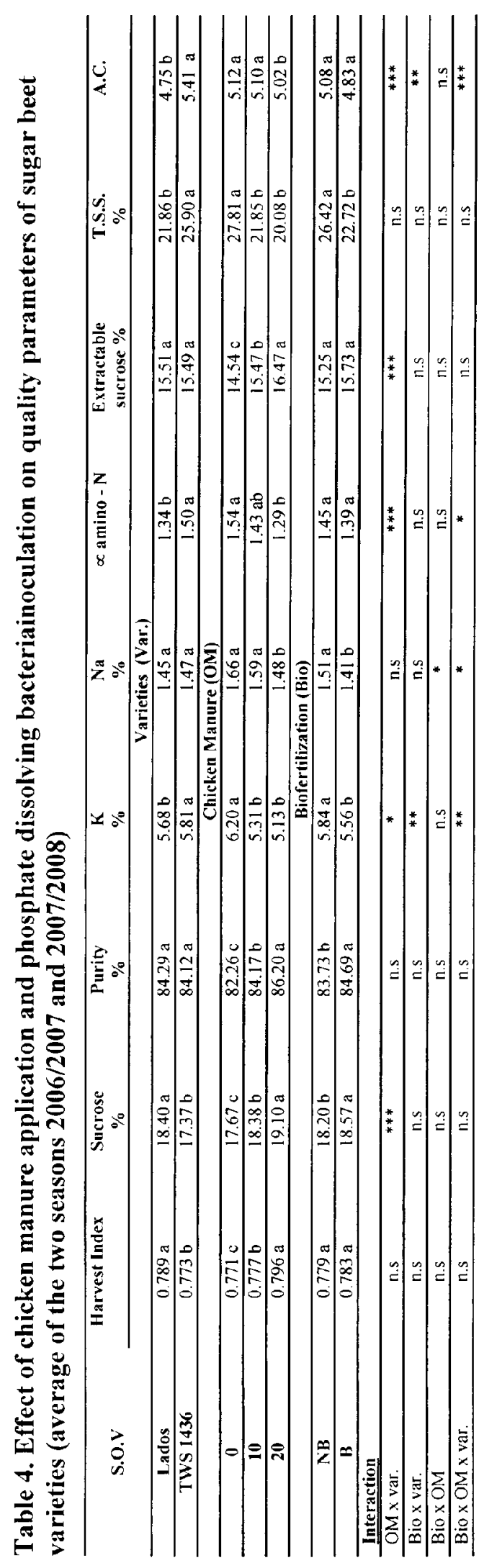


increasing organic matter from 0 to 20 ton/fed.. Similarly, Buraczynska et al., (2001) stated that organic manure generally increased the content of sucrose $\%$. On the other hand, Omar (2007) found that extractable sucrose and purity $\%$ were slightly increased as farmyard manure increased to 15 and $25 \mathrm{~m}^{3} /$ fed. in two seasons. This result

may be due to the reduction in both $\mathrm{K}$ and $\mathrm{Na} \%$. The positive effect of organic matter on purity $\%$ may be attributed to its effect on the impurities (K, Na and $\propto$ amino - N) where organic matter may decrease the accumulation of these impurities in the juice of sugar beet roots and since it is well known that increasing $\mathrm{K}$ and $\mathrm{Na}$ in addition to $\propto$ - amino- $\mathrm{N}$ in the extracted juice negatively affected the extracted sugar.

The increase of organic matter from 0 to 20 ton/fed. led to significant reduce of soluble non sugar \%, T.S.S.\% and A.C. (table 4). Similarly, Omar (2007) indicated that soluble non sugar \% was decreased as farmyard manure increased in the two seasons. These results are agreed with that obtained by Convertini et al., (1999) who stated that organic fertilizer led to a decrease of soluble non sugar \% in sugar beet. Also, Buroczynska et al., (2001) revealed that organic manures generally decreased A.C. of juice of roots. In contrast, Omar (2007) reported that there was no specific trend in A.C. as farmyard manure increased in the two seasons of study. On the other hand, Omar (2007) reported that T.S.S. \% had no specific trend as farmyard manure increased in the first season. However, in the second season, T.S.S. tended to decrease slightly by 2 and $3 \%$ with increasing farmyard manure to 15 and $25 \mathrm{~m}^{3} /$ fed. respectively. The slight reduction in T.S.S. may be due to the reduction in both $\mathrm{K}$ and $\mathrm{Na} \%$.

\section{Effect of biofertilization:}

Sucrose and purity percentages of sugar beet plant inoculated with PDB were increased significantly than those of the other plants without inoculation. Similarly, Afify et al, (1994) reported that, inoculation of sugar beet seed with Bacillus megaterium recorded the highest sucrose for 5 seasons. Also, Abo El-Fotoh et al., (2000) showed that inoculation of sugar beet with phosphorine with half recommended dose of mineral NPK fertilizer gave the highest sucrose and purity percentages compared with control treatment. The same results were obtained by Nour El-Din et al., (2003). On the other hand, there was no significant difference in extractable sucrose $\%$, A.C. and $\propto$ amino-N between both plants with and without bacteria. In contrast, K, Na and T.S.S. percentages were decreased significantly with inoculation by PDB (table 4). In contrast, Mokadem et al., (1999) found that inoculation of sugar cane with phosphate dissolving bacteria leads to increase T.S.S. $\%$ compared with the uninoculation plants. Similarly, Ali (2003) investigated the effect of Bacillus megaterium on quality of sugar beet roots. The obtained data cleared that the percentage of T.S.S. \% was significantly increased when plants inoculated. On the other hand, Badr (2004) found that there was no evidence for significant differences in T.S.S. \% due to inoculation of sugar beet seeds with phosphate dissolving bacteria.

\section{Effect of interactions:}

The interaction between organic matter and sugar beet varieties (OM x var.) had a highly significant effect on sucrose $\%$, $\propto-$ amino-N, extractable sucrose $\%$ and A.C.. On the other hand, it had no significant effect on harvest index, purity\%, $\mathrm{Na} \%$ and T.S.S. \% (table 4). The interaction between biofertilization and varieties (Bio $\mathrm{x}$ var.) had no significant effect on all parameters in table 4, except K\% and A.C. which had highly significant effect. The interaction between biofertilization and organic matter (Bio x OM) had no significant effect on all data presented in table 4 except, $\mathrm{Na} \%$ which had a significant effect. On the other hand, the interaction between biofertilization, organic matter and varieties had no significant effect on harvest index $\%$, sucrose $\%$, purity $\%$, extractable sucrose $\%$ and T.S.S. \%. In contrast, it had highly significant effect on A.C., and had significant effect on $\mathrm{K} \%, \mathrm{Na} \%$ and $\propto-$ amino-N.

From these results, it can be concluded that inoculation with phosphate dissolving bacteria only or in addition to chicken manure significantly increased all sugar beet growth attributes and quality parameters under the same conditions. Also, Lados variety gave higher sugar beet growth attributes and quality parameters compared to TWS 1436 variety.

\section{REFERENCES}

Abd-Elwahab, A.M.; H.M.Abdel-Mottaleb and M.S.H.Yussef (2005) Response of some sugar beet cultivars to two fertilization treatments under sprinkler and drip irrigation systems in newly reclined lands, Sina; the 11the conference of Agronomy, Agron .Dept., Fac. Agric., Assiut Univ., Nov15-16.

AboEL-Fotoh, H. G.; A.A. Abdel-Magid and R. E . Khany (2000). Effect of biofertilization on sugar beet. yield quality and optimization of the chemical fertilizer. proce. 9the conf. Agronomy Minufiya Univ., 1-2sept., 561-567.

Afify. A.H.; F.M.Hammouda; A. M. Basyouny and F. A. Hauka (1994) Effect of bacterization and mineral fertilization on the main characters and major insect infestations of sugar beet plants ,J. Agric. Sci., Mansoura Univ .19(1) : 201-208

Alexander, M. (1997). Introduction to Soil Microbiology. $2^{\text {nd }}$ Ed. John Wiley \& Sons Inc., New York.

Ali, M. H. A. (2003). Microbiological chemical studies on the rhizosphere of sugar beet plants. P.h. D. Thesis, Fac. Agric. Al Azhar Univ., Egypt. 
Badr A. I. (2004) Response of sugar beet plant to mineral and biological fertilization in North Delta. Ph D Thesis, Fac., Agric., AL-Azhar Univ., Egypt.

Black, C. A. (ed.) (1965). Methods of Soils Analysis Parts 1 and 2, Agronomy Monograph No. 9, Madison, Wisconsion.

Buraczynska .D,F.Ceglarek and A.Paza(2001). The influence of different organic fertilization on sugar beet crop in the middle -eastern part of Poland part. technological quality of sugar beet .Roczniki Nauk. Rolniczych Seria A,produkcja Roslinna. 115(1/4):55-65

Buraczynska, D. (2004) The role of green manures, in form of under sown cover crop, and straw in sugar beet cultivation part. Yield and biometric characteristics of sugar beet roots Biuletyn Instytutu Hodowli Aklimatyzacji Roslin. (234):181-190

Convertini, G.; D-de. Giorgio; D ,Ferri; p. la. Cava and LGigolo (1999) Sugar beet and durum wheat quality characteristics as affected by composted urban waste. improved crop quality by nutrient management 241-244

Elham,, A. Badr, (2006) Effect of organic, biofertilization and plant density on yield and quality sugar beet $\mathrm{Ph}$.D .Thesis Fac., Agric. (SabaBesh)Alex . Univ., Egypt .

Gomaa,A.M.H(1995) Response of certain vegetable crops to biofertilization $\mathrm{Ph}$.D.Thesis ,Fac.Agric .,Cairo, Univ . Egypt.

Gomez,K.A.and A.A.Gomez (1984). Statistical procedures for agricultural research an international rice research Institue . book john willey and sons. Inc., New York.

Gonzalez G ;Gonzalez; Moya, Nisosa , D.and olivera ,W.(1995) Effect of inoculation with Azospirillum and three levels of nitrogen in sugar cane in vitro .Pastos -YForrajes, 18:3,245-249

Harvey , C . W. ; and J . V . Dutton (1993) Root quality and processing, pp . 571-617in the sugar beet crop. Science into pratice Edited by D . A . cook and scott published by chapman and Hall . London

Hassan , W . M .(2005) Effect of some organic fertilizers and sulphur application on yield quality and nutrient contents of sugar beet J . Adv. Agric .Res ., 10(4) :965-977

Hepper, C. M. and A. Warner (1983). Role of organic matter in growth of vesicular arbuscular mycorrhizal fungus in soil. Trans. Br. Mycol. Soc. 81: 155-156.

Ibrahim, O. M; (2007) Effect of potassium and organic fertilizer on the productivity of some sugar beet varieties under saline conditions Ph .D. thesis,Fac ., Agric ., Alex ., Univ ., Egypt

Jackson,M.L.(1967) Soil chemical analysis New Delh ,prentice Hall af India private limited Delhi , pp326-338

Kapoor, K. K. (1995). Phosphate mobilization through soil microorganisms. In: Behl RK, Khurana AL, Dogra R C (eds) Plant microbe interaction in sustainable agriculture.
CCS Haryana Agriculture University, Hisar and MMB, New Delhi, pp. 46-61.

Khalil,S.M;N.Mostafa and Z.R.Mostafa (2001) Influence of potassium fertilizer and soil salinity on chemical composition of sugar beet . Minufiya J.Agric. Res. Vol. 26No.3:583-594

Kucey, R. M. N. (1988). Effect of Penicillium biloji on the solubitity and uptake of $\mathrm{P}$ and micronutrients from soil by wheat. Can. J. Soil. 68:;261.

Lowther, J. R. (1980). Use of a single $\mathrm{H}_{2} \mathrm{SO}_{4}-\mathrm{H}_{2} \mathrm{O}_{2}$ figest for the analysis of Pinus radiate needless Comm. Soil Sci. Plant Analysis, 11:175-188.

Marinkovic, B.; L. Starevi ; J. Crnobarae; G . Jacimovic and M . Rajic (2004) By products of sugar beet - quality animal feed . Glasnik Zastite Bilja .27(5): 114-118 Marrge , M . Fand S. T. Bard (2001) Impact of three soil bio-fertilizers applied separately and in combination with a Beatified on meloidorgne incognita infecting sugar beet. Egypt. J .Agron . matology , 4 (1-2):1-9

Mokdem, Sh. A .; E. M. Taha ; and M. A. Abo-Baker (1999) Effect of nitrogen fertilization and bacterial inculation on the productivity of sugar can. Minia J Agric. Res. and Develop ., vol . (19) 161-186

Negm,M.A;M.M. Salib and H.EL-Zaher (2003) A field trial on bio-composite sulphur application for improving the productivity for soil calcareous in natural Fayoum J.Agric . Res. and Dev., 17(1):77-89

Nemeat -Alla, E . A .E . H(2004) Effect some agronomic practices on yield and quality of sugar beet. M .SC. thesis, Fac . Agric ., Kafr EL-sheikh ,Tanta Univ., Egypt

Nour EL-Din , N . A., M . A . EL-Gawad, M .F . Hamed ; A . H . Nassar and S .R . Khalid (2003) Response of some sugar beet varieties to mineral and bio-bio-fertilization under Egyptian environmental studies and Res., Ainshams Univ., 4 (1) :163187

Omar, M. I. (2007). Effect of potassium and organic fertilizer on the productivity of some sugar beet varieties under saline conditions. PhD thesis, Fac Agric. Alexandria Univ, Egypt.

Patil P.L(1985) Recent advances in technological development in the field of biofertilizers :Azotobacter, national seminar on biofertilizers Viggan Bhavan, New Delhi, Octoer 1986

Radfords., P.J.(1967). Growth analysis formula, the rise and abuse crop Sci., 7:171-175

Soedarjo, M. and Habte (1993). Vesicular arbuscular mycorrhizal effectiveness in an acid soil amended with fresh organic matter. Plant and Soil 149: 197-203.

Stumpe,H.,L.Wittenmajer; and W.Merbach (2000) Effect and residual effect of strow, farmyard manuring, and mineral fertilization at field of the long -term in Halle (Saale), Germany. Journal of plant Nutrition and soil science. 163(6): 649-656

Watson, D.J. (1958) The dependence of net assimilatiom rate on leaf area index Ann . Bot . lond .N. S., 22:37-54. 


\section{الملخص العربي}

\section{إستجابة صنفين بنجر السكر لسماد الدواجن والفوسفورين}

$$
\text { إسلام إبراهيم أبوالسعود، إلهام عبدد المنعم بدر، الشيماء عبد المولى السيد }
$$

ليس هناك فروق معنوية ما بين النباتات الملقحة وغير الملقحة بالبكتريا بكل من amino -N بكل النسب المئوية للسكر الذائب ومعامل القلوية و على العكس فإن النسب المئوية لكل من البوتاسيوم والصوديوم والمواد.

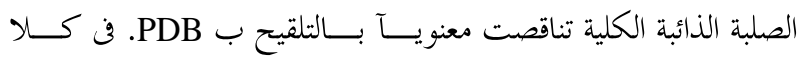
الصنفين بنحد أن إستجابة نباتات بنجر السكر الغير ملقحة بــال PDB

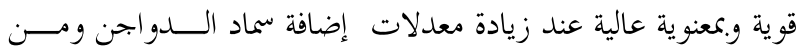
ناحية أخرى بند أن نباتات بنجر السكر الملقحسـة ب PDB تعطى إختلافات طفيفة وغير معنوية عند المستويات المختلفة من المادة العضوية

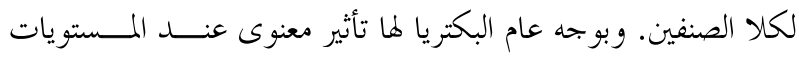

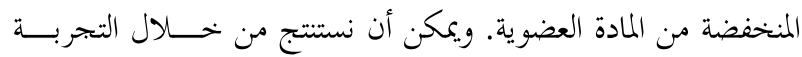
السابقة أن التلقيح بالبكتريا المذيبة للفوسفات بصورة منفردة أو إضافة

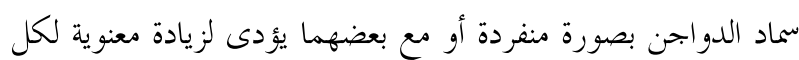
معدلات نمو بنجر السكر والجودة تحت نفس ظروف هذه التجربـــة. كذلك صنف أعطى أعلى معدلات نمو وجودة لبنجر السكر مقارنة بصنف TWS1436.
أجريت هذه التجربة هدف دراسة تأثير كل من المادة العــضوية (سماد الدواجن) والتلقيح بالبكتريا المذيبة للفوسفور (الفوسفورين) على

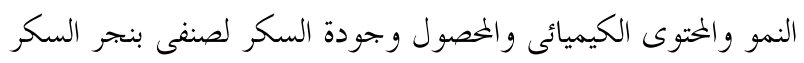

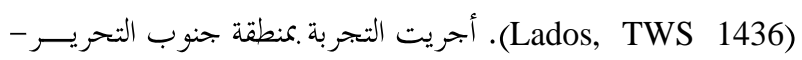

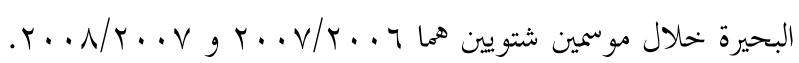
تم تصميم التجربة بنظام القطع المنشقة المنشقة مع ع مكررات. أشارت

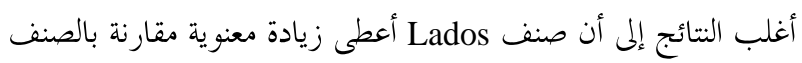
الأخر TWS1436 في كل تقديرات النمو وجودة بنجر السكر ما عدا

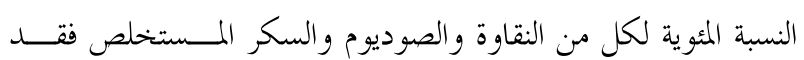
أعطوا فروق غير معنوية. كذلك قد أشارت النتائج إلى أنـــهـ بزيــادة

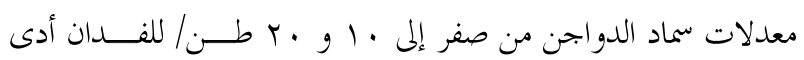

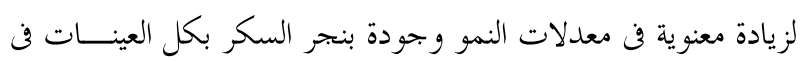
كلا الموسمين ما عدا النسبة المئوية لكل من المواد الصلبة الذائبة الكليـــة ومعامل القلوية فقد تناقصا معنويآ خلال الموسمين. زادت معنويآ جميع قيم صفات النمو للعينات خلال الموسم والحصاد خلال الموسمين مــع

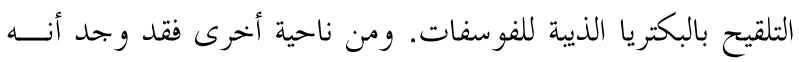

